\title{
The Role of the Family in the Restoration and Preservation of Yoruba Cultural Heritage
}

\author{
Emmanuel Oluwasegun Awofeko \\ McPherson University, Nigeria \\ emmashalom2004@yahoo.co.uk
}

Olatunji Olusegun Oyebanjo

Tai Solarin University of Education, Nigeria

lovingsheg@yahoo.co.uk

Oluwaseyi N. Shogunle, Olabisi Onabanjo University, Ago-Iwoye, Nigeria seyishogunle@yahoo.com

\begin{abstract}
Yoruba people have a unique cultural heritage which engulfs every aspect of their lives; hence, guides them in their daily activities. It was borne in their heart, incise in their offspring, and pass from one generation to another. Unfortunately, this cultural heritage is almost lost today, as civilization has denigrated almost all these cherished cultural values in Yoruba communities. Undoubtedly, the family where the whole cultural decadence started from has great roles to play in restoring and preserving these cultural values. This is the thrust of this work. The essay is therefore approached from historical and ethical perspectives with phenomenological methodology to examine the cherished Yoruba cultural heritage. The findings of the work show that moral training through informal education; means of identity; communal responsibilities; ascribed roles; etc., are missing among the youths today. The paper adopts Mary Jo Hatch's theory of cultural dynamics to examine the changes in Yoruba cultural heritage, the causes of decadence of this heritage; and the role of the family in enthroning Yoruba cultural heritage among the youths today. The essay recommends that family needs to rise for the restoration and
\end{abstract}


preservation of these cultural heritages to combat the socio-cultural threat confronting the society.

\section{Introduction}

For over two decades, the practice, propagation, and eventual ubiquity of Yoruba culture that define and identify the Yoruba people within and outside their territory has experienced a sudden disappearance. Such cultural values and practices include acceptance and practice of core native language names, tribal marks, etiquettes, observance of taboo, accordance of rites, morality, etc. Undoubtedly, as far as people are living together in groups, shared beliefs, customs, practices, and social behavior which are known as "culture" is inevitable in a given geographical area. So, it is evident among the Yoruba people of Southwest Nigeria. Although this cultural value was formalized by the forbearers of the Yoruba, the values are made into arbitrary standards of conduct in the society, which are passed from one generation to another. This cultural heritage has diminished in today's Yoruba society.

The negligence, defiance, desertion, and disappearance of this cherished cultural heritage have brought about decadence in the Yoruba kingdom and the entire nation at large. Adepoju and Awofeko opine that the decline of a societal culture and moral values do have negative effects on the society, which result to wanton flouting of laws, menace, social vices, anarchy, societal collapses, loss of unity within a nation, inner conflict and eradication of moral behaviors in the society. ${ }^{1}$ Yoruba is not exempted from these, and severely affected by relinquishment and decadence in her culture. Among many other factors one could identify like: acculturation, indoctrination from the western religions, abuse of technological appliances, etc., as causes of loss and decadence of cultural heritage in Yorubaland, the family should be focused at, to have failed in its obligations to retain and sustain what is delivered unto her by past generations.

Family, although regarded as the smallest unit in the society, cannot be ensconced from, to have a functional society, and smooth-running of such society because this smallest unit developed to what we know as society. ${ }^{2}$ It is a fact that every occurrence in the society begins from the family. Therefore, family has a great role to play in the sustenance of cultural values of any society. In the light of the above, this essay seeks to examine the causes of

1 Adepoju, A. and E. Awofeko. "Socio-Ethical Implications of Westernization on Indigenous Cultural Values among the Yoruba People." Journal of Religion and African Culture. Vol. 4.1, (2016): 80.

2 Enrique, J.; Howk, H.; \& Huitt, W. "An overview of family development”. Educational Psychology Interactive. (Valdosta, GA: Valdosta State University), 2007. Retrieved July 8, 2017, from http://www.edpsycinteractive.org/papers/family.pdf 
negligence and disappearance of Yoruba cultural heritage among contemporary Yoruba families; and therefore, suggests practical ways of restoring and preserving the cultural heritages.

\section{Theoretical Framework}

This paper predicated on cultural dynamics theory propounded by Mary Jo Hatch, which is a viable tool to examine relational patterns, trends and processes in cultural issues. The prototype of this theory focuses on both the objective and subjective aspects of cultural processes in a defined organization. Hatch based her theory on anthropological, as well as social constructionist traditions, and concludes that cultural processes - manifestation, realization, symbolization and interpretation of cultural values - account for both cultural change and stability. ${ }^{3}$ Two major questions were raised in this theory. They are: how does cultural value change; and who or what changes them? Hatch, in her theory, cultural dynamics, integrated Schein's three level conceptual models of 'artifacts', 'values' and 'assumptions' with the concept of symbol into her own concept of cultural processes, which are identified in four aspects: manifestation, realization, symbolization and interpretation. Schein's three level conceptual models are defined thus:

Assumptions represent taken-for-granted beliefs about reality and human nature. Values are social principles, philosophies, goals, and standards considered to have intrinsic worth. Artifacts are the visible, tangible, and audible results of activity grounded in values and assumptions. ${ }^{4}$

Of note, most changes in cultural heritages occur due to influences from other culture. This happens, for instance, when cultures are merged or have other forms of contact with foreign culture especially in the current globalized world in which we live, are not closed; they are continuously bombarded by potentially influential new cultural material. This argument is supported by Weber that "all change in culture originates in the introduction of new ideas by a charismatic figure, but change at the level of everyday life follows the path of routinisation of this charismatic influence." 5 Schroeder's perceptive study of Weber's theory of cultural change discovered three pillars: the routinization of charisma; the differentiation of the spheres of life; and the inner logic

3 Hatch, M.J. "The cultural dynamics of organizing and change". In N. Ashkanasy, C. Wilderom and M. Peterson (eds.) Handbook of organizational culture and climate, (Bedford: Sage Publisher), 2000: 245-260.

4 Hatch, M.J. “The dynamics of organizational culture”. Academy of Management Review, 18.4, (1993): 659.

5 Weber, M. Economy and society. (CA: University of California Press), 1968. 
of worldviews. The routinization of cultural change occurs when there is either directly hereditary transmission of cultural value to others or devolves as a concept upon a group of followers.

\section{Cultural Heritage of the Yoruba}

Yoruba people have a unique cultural heritage, especially in the aspect of morals and etiquettes among others, which makes them stand out among other ethnic groups in Nigeria. Atanda argues that their cultural heritage is a derivative of their religion, which to a large extent, has formed their norms, values, beliefs, customs, practices, and social behavior. It regulates their ways of life and gives a high standard of morality. ${ }^{6}$ Adepoju and Awofeko support this notion that "their culture dictates, instructs, teaches, guides, guards, and leads them in their daily activities, that is, it involves every aspect of their religion. This culture envelopes the religion they practice... Religion devolves into every aspect of the cultural life of the people." 7 This means that Yoruba cultural heritage engulfs every aspect of their lives and guides them in their daily activities. This cultural heritage is borne in their heart, incise in their offspring, and pass from one generation to another.

Indisputably, culture is fundamental, perhaps the most important, influence in the life of the Yoruba. However, its essential principles are too often unknown to foreigners who constantly misconstrue these beliefs and practices. Irrespective of the whims of modernity, the Yoruba people still hold tenaciously to their cultural practices and traditions so dearly in spite of the fact of many challenges that waged war against these cultural values. Similarly, every society has its own cultural beliefs and practices, with a system of inculcating them to succeeding generations. Therefore, everything done in such society is largely exhibited in the culture of the land. Be it in terms of style of dressing, food, makeup and jewellery, relationship with one another, special symbols and codes. ${ }^{8}$ As such, Yoruba, like other people elsewhere, have their own culture, which is their heritage and it is well-known globally. The following are discussed as major aspect of the Yoruba cultural heritages:

\section{Education}

The act of imparting and acquiring knowledge through teaching and learning was done in Yorubaland through its informal and non-formal ways. The people train their children from infant through adulthood. This teaching and

6 Atanda J.A. An introduction to Yoruba History. (Ibadan: Ibadan University Press), 1980: 28-29.

7 Adepoju A. and E. Awofeko. "Socio-Ethical Implications of Westernization”, p.81.

8 Adepoju A. and E. Awofeko. "Socio-Ethical Implications of Westernization”, p.82. 
training cut across every aspect of life. Fafunwa summarizes the objectives of this teaching into seven-fold agenda of educating young ones. These are: i) to develop the child's latent physical skill; ii) to develop character; iii) to inculcate respect for elders and those in position of authority; iv) to develop intellectual skills; v) to acquire specific vocational training and healthy attitude towards honest labor; vi) to develop a sense of belonging and participate actively in the community affairs; and vii) to understand, appreciate and promote cultural heritage of the community. ${ }^{9}$ Furthermore, the people impart knowledge, especially morals, through stories, pithy sayings, adages, epigrams, riddles and other wise sayings which are vehicles through which historical events are known and kept. Indigenous cultural values are conveyed to instil moral, settle quarrels, teach young ones, encourage, and warn implicitly or explicitly against evil conducts or impending dooms in the community.

\section{Means of Identity}

The distinctiveness of the Yoruba people has shown in various ways. One of these ways is their means of identity. Dressing is very significant among these people. It speaks volume of how unique and exceptional they are. It is factual that clothing is generally used to cover nakedness, but in addition, the Yoruba use it as a means of identification among other people. Oyeniyi identifies that the people have different kinds and styles of clothing. We have bàbárigá, şòkòtò, agbádá, filà (cap) for males; and bùbá, iró, gèlè (head gear) for females. ${ }^{10}$ Yoruba people are easily identified with their ways of dressing. Besides dressing, tribal marks is another means of identifying the people. This varies from one ethnic group to another within the Yoruba kingdom. In ancient times, each clan in Yorubaland has its own style of tribal mark, which made it very easy to identify anybody from such clan. Language, a system of communication with its own set of conventions, is another feature of identity among the people. Similar to tribal marks, each ethnic group in Yorubaland has its own dialect, which is cherished and spoken fluently anywhere without code-mixing and code-switching unlike what we have today. In addition, name, another means of identity, plays a pivotal role in identifying Yoruba people. Names of places and human beings in Yorubaland have cultural meaning. Names are part of cultural heritage of the Yoruba, as it gives brief explanation to happenings or events that birthed such name. Examples are: 'Abídèmí' (a child born while the father was away), 'Kòkúmọ̀', 'Bámitálẹ́,

9 Fafunwa, A. Babs, History of Education in Nigeria. (Onitsha: NPS Educational Publishers Ltd), 2004: 7.

10 Oyeniyi, B.A., Dress and Identity in Yorubaland, 1880-1980. (Doctoral thesis, Leiden University), 2012. 
'Durosìmì', 'Màlọmộ' (these names indicate that the parents lost several children before the birth of the bearer of any of the names), 'Iyábọ', 'Babátúnde' (means the mother or father of the parents died not too long before the birth of the child), etc. The saying, ilé là ń wó, ká tó s'ọmọ l'órúkọ (one considers the circumstances of the home before naming a child) is an indication that names given to people in Yorubaland is far different from how other tribes name their children.

\section{Health issues}

To the Yoruba people, well-being does not merely connote the absence of ailments and diseases, but also encompasses the proper physical, mental, and social functioning of humans. In Padonu's work, ilera l' orọ (health is wealth), an apothegm in Yoruba society, is borne out of the realization and fact that without good health, productive functions and activities could hardly be carried out effectively. ${ }^{11}$ This is far beyond what other ethnic groups count as being healthy. Àlááfía ju ohun gbogbo lọ (good health surpasses all other things), which connotes that without good health, man is weak and helpless. Man is occasionally faced with one adversary that negates or denies him of enjoying sound health. In his work, Omonzejele explains that this adversary is known as "disease" (a hindrance to wellness of any human being). Disease is interpreted in many ways to the Yoruba people. It goes beyond inability to move around or pains within the body, but absence of comfort and affluence (dis-ease), and/or inability to experience or enjoy peace in one's life on daily basis. ${ }^{12}$

Explicitly, any problem that a man faces is a 'dis-ease'. Yoruba has three aspects of tackling their health issues/challenges. These are: diagnosis, healing and prevention. It is disheartening to note nowadays that this aspect of cultural heritage is neither known nor adopted by many Yoruba people. Diagnosis is the ability to identify illness or disorder in a person through physical examination, medical tests, or other procedures. It is the discovery of the nature of a disease. But Yoruba people believe in using herbs, natural observance, and divination to discover a disease (dis-ease) of any type. Once this is discovered, solution (through ritual, sacrifice, herbal dosage, etc.) is recommended to avert it. Healing is the ability to bring an end to any discovered dis-ease. Yoruba believe that once an illness or disease is identified, traditional healing method (hydrotherapy, divination, and herbal method) is adopted to

11 Padonu, M. K. The Role of Traditional Medicine in Primary Healthcare Delivery in Nigeria. (Ibadan: Samtol Press), 1997:53.

12 Omonzejele Peter. "African Concepts of Health, Disease, and Treatment: An Ethical Inquiry”. The Journal of Science and Healing, Vol. 4(2), (2008):121. 
terminate it. Prevention is the act of avoiding something from happening. In a simple form, a preventive method adopted by the people is how they measure their daily activities to avoid any form of dis-ease or illness in their lives.

\section{Rites of Passage}

Rites are symbolic and powerful means of expressing both cultural and religious beliefs in any society. Mbiti acknowledges that African society is filled with many ceremonial acts which mark important events in the life of the community in general or the individual members in the society. ${ }^{13}$ Thus, rites of passage are used to mark a transition from one state of life to another. Life follows particular circuit which is made up of important stages. These stages are ritualized and marked with various rites. They are:

i. $\quad$ Birth Rite. The blessings, fruitfulness or success of any marriage in Yorubaland are calculated in terms of number of children a couple has. Birth is therefore regarded as an important period in the life of Yoruba people. It is one of the means of ensuring the continuity of human race. The Yoruba, right from the time of conception of a woman through delivery, have cultural rites like exercise, posture (standing/sleeping), food, movement, limitations, mood, burying of the biblical cord, etc. that guides and guards the couple to avoid calamity for both the child and the mother. In addition, the futurity of the child is examined through divination known as èsẹ̀ntáyé to enable both the parents and the child to be cautious of its revelation.

ii. Puberty Rite. These are rites that are used to mark the end of childhood and beginning of adulthood, and acceptance into matured group in the society. It is one of the occasions in one's life when certain knowledge that cut across all aspects of human activities and adult life is vigorously given. It involves core procedures for teenagers, especially during the first menstrual period of a lady.

iii. Marriage Rite. In Yoruba cultural context, marriage rite is a social contract between a man, a woman and their extended families. Before marriage is finally contacted, many preliminary activities, which are the core cultural heritage of the people, ranging from inquiries, proposals, acceptance and official engagement or courtship and payment of bride price must have been completed. These cultural activities elongate and preserve the marriage, rather than mere

13 Mbiti, J. S. Introduction to African Religion. (New York: Heinemann Press), 1991:4 
ceremonial as we have it today.

iv. Death Rite. Yoruba see life as a continuum; death is therefore seen as a passage to the hereafter. Rite performed for the dead makes its transition from the physical existence to the invisible existence smooth and easy. Therefore, the corpse is given special rites before it is buried. It is believed that the dead would perturb its relatives and does not settle in the land of the dead if it is not given befitting burial rites.

\section{Taboo}

Taboo is a social or cultural prohibited act. In many African cultures generally and Yoruba specifically, people are not allowed to do everything the way they would want to do them. Certain actions and behaviors are prohibited. In such case, one does not exercise his or her freewill in performing such actions; thereby conform to the law of the land. Many taboos are associated with divinities, religious authorities, ancestors, trade and crafts, agriculture and many other relevant areas of life. And should there be any breach; the offender may face certain consequence either physically, psychologically or spiritually before he or she will be cleansed through a ritual. However, some taboos do not have any repercussion because they are meant to enhance moral acts. There are many forms of taboos in Yorubaland; some are religiously inclined, while others are connected to social or moral etiquettes. Examples are: It is a taboo for a child to receive something with a left hand from an elder; it is a taboo to beat somebody with a broom or pestle; whistling in the night is forbidden; it is a taboo for a child to beat his or her parents; etc.

Individuals in Yorubaland are very conscious of the consequences of breaking taboos. Individuals and collective efforts are always made towards observing these taboos. A system of taboos and sanctions held in honor of the ancestors, divinities and spirits are used in Yoruba societies to enforce or maintain sanity/morality. Similarly, taboos in Yoruba societies are evil deeds, such as robbery, murder, rape, sorcery, witchcraft, poisoning, suicide, sexual intercourse with animals, incest, etc. are forbidden and abominable. The people believed in the law of 'cause and effect' and the transference of punishment for an abomination or offense committed by a parent to his children or generation. These are therefore strictly adhered to. The consciousness and adherence of these ill actions had guaranteed peace, harmony, growth and development in the Yoruba societies. 


\section{Festivals}

African indigenous religion is full of programs (series of performances and cultural events), usually held at regular intervals, often known as festival. Festivals are special periods of worship which are esteemed by the Yoruba. They are festive periods when people gather together to honor and thank their gods, divinities, and ancestors. Most of them are annually observed, but some can be biannual. Some are used to commemorate significant events in the life of the community, while others are used to mark the beginning or the end of important seasons or year. Although, festival is religiously inclined, it is seen as part of culture, which marks one phase of circle from another. For example, the beginning of planting season and harvest season are marked with special festival. The Yoruba have special festivals and very significant to them. Among the popular ones are ògún, egúngún, orò, agẹmọ, ọsun, ojúde-ọba festivals. Aside merriment, people pray and mark it with one good thing or the other.

\section{Intellectual Skills/Vocational Training}

Every family in Yorubaland has a particular occupation, profession or trade they are known for. This family occupation is mandatory for children of such family in addition to any other vocation they (may) decide to do. This culture of family vocation helps children to be versatile as they grow. Beside this, children were enrolled to learn vocations in line with their interest as detected by elders in the family as they grow, which they depend wholly on for their daily living. This has helped to boom the economy of the Yoruba people.

\section{Communal responsibility}

This is a culture of the Yoruba people that unite them together and assist them in building lives and the entire community. It deals with collective and individual's obligation in the family and the entire community that gears towards achieving the common goal. The people, especially elders, take it upon themselves to instil cultural values and discipline on individuals (especially the youngsters) in the society. Hence the saying, enikán ni bi omo, igbà èniyàn ni $n$ wo o (it is one person that gives birth, but several people care for the child). Also, people voluntarily put it upon themselves to see to the wellbeing of others in terms of security, polity, economy, development, etc.

\section{Chastity}

Virginity (ibálé) is a virtue kept by unmarried and appreciated by all in Yorubaland until late $20^{\text {th }}$ century. Besides the grave punishment (disgrace, humiliation, etc.) attached to its victim, sexual intercourse is sacred and must be performed mainly by bonded couple. Yoruba culture permits polygamy, 
rather than sexual impurity. According to Awofeko and Adeyemi, there are several pejorative terms used to describe any women caught or suspected to be infidel, for examples, aláipé (incomplete person), àikáràgbá (broken calabash), àlòkù (used or worn out), ajòdí ikòkò (broken pot), aláilójútì ajá (shameless dog), alágbèrè (owner of low moral or prostitute), aşéwó (promiscuous) and onişe-kúşe (corrupted). In addition, chastity in Yoruba culture is believed to build a woman's self-esteem; breed trust in marriage; promotes personal decency; prevents Sexually Transmitted Infections (STI) and unwanted pregnancy; and identifies sluts in the society. ${ }^{14}$

It is disheartening, heartbroken, and inexplicable that the unique and cherished cultural values (as listed above) handed over by the Yoruba forbearers are vanishing from the society today. Unfortunately, the present generation hardly know that these cultural values neither existed nor practiced. Adepoju and Awofeko lamented that the disappearance and decadence in African cultural heritage is inevitable as acculturation, which civilization brought through formal education; indoctrination through foreign religions; abuses of modern and sophisticated machines/devices; among others have wrecked the Yoruba cultural heritage. As good as civilization brought to the land through formal education is, its negative impacts have overshadowed Yoruba indigenous cultural values. ${ }^{15}$ Undoubtedly, this has affected (still affecting) the people with many dying very young due to modern ways of handling their health; catastrophes hither and thither attributable to improper observance of rites, infringement of taboos, and abandonment of identity; suffering due to lack of vocational training and/or intellectual skills; nudity in the streets as a result of indecent dressing; menaces and vices in the society because the family and individuals in the society have failed in their responsibility to restore and maintain cultural heritages handed over to them.

\section{The Concept of Family in Yoruba Society}

Family can simply be referred to as the smallest unit with group of individuals related by blood, marriage or connection, who influence one another at all time. It can also be seen as a group of individuals who share a bond and are related through blood, a web of experience, belief system, values, emotions, and a fostered culture. Atanda is of the opinion that "the Yoruba, in the course of their development, evolved a social organization in which the

14 Awofeko, E.O. and T. Adeyemi. "Ethical Assessment of Virginity in the Old Testament and Yoruba Socio-Cultural Context". Journal of Studies in Humanities, Vol. 9, (TASUED-JOSIH), 2018: 185.

15 Adepoju A. and Awofeko, E. "Socio-Ethical Implications of Westernization..., pp.86-87. 
lineage, ẹí or idílé is basic." 16 The word ẹbi describes and defines the typical Yoruba family, which is relative in meaning. According to Shitta-Bey, e ebi

could connote members of a family living together in one household. ${ }^{17}$ The main reason each individual is identified by the family name, and not just father's name. Also, it could connote a clan, a family bond far beyond what obtains in the western world - a nuclear family. This is often referring to $a g$ bo-ilé. Ébi means that an individual in a family has connections with other individuals outside the immediate household; this may occur through marriage, adoption or redeemable slaves. ${ }^{18}$

\section{Recommendations: Rediscovering the Role of the Family in Yorubaland}

It is realistic and evident that Yoruba have a unique family structure that is community-based, which form the grassroots administrative structure that other tiers within the society are built. Two family levels are common among the Yoruba people, which are the immediate or nuclear family level, and the kinship or extended family level. However, these two levels emphasize both blood and marital relationships. Typical traditional Yoruba families are customarily patrilineal and patrilocal in nature. ${ }^{19}$ This has made it easy for the whole family members to oversee what individuals (especially the young ones) are doing. The axiom, ilé la tín k' eşsọọ r'òde (charity begins at home) is the watchword of each family in discharging their 'ascribed' and 'obligation' roles effectively and efficiently towards preservation and continuity of the cultural values in the family and the community.

Disappointedly, reverse is the case in Yoruba community today, as family structure has totally changed from what it used to be, and thereby brought shame and lamentation to the Yoruba nation through its nonchalant and lackadaisical attitudes towards restoration and preservation of Yoruba cultural heritages. What is the way forward in restoring cherished Yoruba values? For restoration (and then preservation) to take place, the families in Yoruba communities have to be conscious of the present state of Yoruba cultural heritage, and compare it to how it was in the antiquity. First and foremost, the family is expected to wake up to its responsibility, by teaching of morals based on

16 Atanda, J.A. "The Yoruba People: Their Origin, Culture and Civilization" in Olatunji, O.O. (ed), The Yoruba: History, Culture and Languages, (Ibadan: Ibadan University Press), 1996: 18.

17 Shitta-Bey O. Abdul, "The family as basis of social order: insights from the Yoruba traditional culture". International Letters of Social and Humanistic Sciences, Vol. 23, (2014): 82-83.

18 Fadipe, N.A. The Sociology of the Yoruba. (Ibadan: University Press), 1970: 99-100.

19 www.africa.uga.eduYorubaunit_03cultureunit.html 
the standard in the Yorubaland, and enforce strict observance of the cultural values of the land on their children. Gunindi, Sahin, and Demircioglu affirm that the family's responsibility is far beyond making children to grow, get them socialized with others, and find their own identity within the society, but more importantly, must reflects the culture as well as values, structure, expectations to develop oneself and the society, with strict adherence to the rules in the society. ${ }^{20}$ Families should appreciate the Yoruba native creativity, inventions and language, thereby making it their number one choice without foreclosing knowledge from other climes. Each members of the family should wake to take responsibility of his/her ascribed roles on the subject matter. People in authority or leadership positions, who emerge from one family to that post/position, are expected to put the generations coming behind them in the centre of their policies. This means that government should inculcate these cherished cultural values into the curriculum for teachers and instructors to pass it across to their students.

In addition, listed below are the way-forward to enthroning cultural values among the youths in the contemporary society. These have been ways of preserving the cultural heritage of the people but are missing today. The family is expected to revisit these cultural patterns, where the cultural values and heritages can easily be learned or discovered. They are:

\section{Biographies and Legends}

Legends and biographies: mythologies, folktales and biographies are veritable goldmines for youths to keep them abreast of Yoruba cultural values. They are prehistoric cultural attempt at answering the most perplexing questions posed by the supernatural and natural phenomena. They are also vehicles for conveying a certain fact about human's experience in his encounter with the created order and with regard to man's relation to the super sensible world.

Myths, fables, tales, memoir, life history, folklores or stories - are naturally clothed with experience and past events, which serve as means of revisiting the past, unwrapping knowledge, and keeping them in the memory as well as handling them down from generation to generation. There used to be gathering of children with elders in the evening (almost on daily basis) to listen to witty sayings (tales, stories, folktales, etc.) to learn and acquire various knowledge.

20 Yunus Gunindi; Fatma Tezel Sahin; and Haktan Demircioglu, "Functions of the family: Family structure and place of residence". Energy Education Science and Technology: Social and Educational Studies, Volume 4.1, (2012): 549-556. 


\section{Song, Dance and Drama}

Yoruba songs are loaded with meaning and knowledge. These songs (lyrics, ballads, etc.) reveal stories of the past, present, hope and fear of the future. The people also use songs to warn, hail insults, encourage, entertain, eulogize, etc. Songs are meaningful, they express feeling of joy or sorrows or thanks. It also enhances emotional and physical participation in an act of worship which sometimes results to ecstatic experience and ring of men ages from the divinities. Songs can be seen as a vehicle for conveying certain sentiments or truths. Besides, through songs, certain information about Yoruba cultures were made known. Dance and drama are exciting, tense, and gripping events and actions in a real-life situation that impact people through its styles and actions.

\section{Witty Saying}

This is another rich area where moral values are instilled in children. It is a repository of indigenous wisdom, values and feelings. Witty sayings proverbs, riddles or idioms - are coined with past experience or events of the Yoruba people. It is the oldest and authentic forms of cultural practices of the Yoruba people. It is easy to remember, hit the point in a few words and through it reinstates sanity in a situation. Witty sayings are also used to settle quarrels, warn people against bad conducts, encourage and praise people among others.

\section{Names}

Aside the fact that names are means of identifying people or places everywhere in the world, they are also loaded with meanings. There are various facts that are hidden on the cultural heritage of the Yoruba people, which names (in most cases) give details or a clue. It is customary to incorporate God/deity's name into people's name in Yorubaland. This is an expression of worship where the attributes of God are known. Thus, names become life-long testimonies of particular concepts of God/deity which people want to express and when so used, the concepts are immortalized, made concrete and externalized. 'Olọrunfúnmí', meaning 'God gives me' expresses the providence of God among the people. Others are Ifágbèmí meaning 'Ifá favors me'; Awóyẹmí meaning 'Awó cult favors me’; Ògúnbáyò meaning 'Ògún births joy', etc.

\section{Books}

This documented imaginary records, past events, hidden ideas, repository of knowledge, among others. Scholars have made rigorous efforts to work on Yoruba people, their culture and religion. They have revealed, to an extent, past historical events through their research, which can serve as reasonable 
guides to both young and old; young scholars and readers. These books are helpful because they expose historic events, defined cultural values and heroes of the Yoruba people.

It is obvious that the above are missing today in most Yoruba communities, which could have helped in restoring the lost Yoruba cultural heritages. Cultural relevance of some of them have been replaced or totally lost where they are practiced. Advancement in technological devices that should have contributed to preservation of cultural heritage has become a woe because the family has failed in its responsibilities in the home and the entire community to positively monitor and tailored its use to the standard of the land. The family among other agents of socialization in the community should facilitate the return of this cultural values, encourage, guide and guard youngsters in selected programs on radio and television programmes, art performances, songs and dances, training, seminars, and the likes, that can enhance their knowledge on these values.

\section{Conclusion}

From the foregoing, it has been established that moral decadence, a cankerworm that has dealt a deadly blow on the ethical psyche of the Yoruba cultural values, cannot be dealt with without the rigorous effort from and/or of the family. As established through Hatch's theory that change is constant to anything, including culture of any society, so it is to Yoruba cultural heritage. However, since culture is not static, family should take it upon itself to ensure the restoration of these cherished cultural heritages. Timehin, in his work reveals that instant and measured punishment serves as basis for enforcing deterrence to offenders or anyone that act contrary to the culture of the land, which was conceived in two ways in the past: any offender caught is punished based on the weight of his/her crime; while nemesis is the second measure of punishment to offenders. ${ }^{21}$ Thus, these measures made the people to be distinct as a peculiar people. They live in a peaceful environment of collective responsibility, where love, harmony and trust were present as a result of deep understanding and practice of cultural values, to the extent of people leaving their goods in the open and no one dare steal or cheat them. It is guaranteed that Yoruba nation will be far better than the present time if their lost cultural values are restored and practiced, and serve as a means of solution to the problem of corruption, selfishness, recession and unfaithfulness in economy, politics, leadership, among others through industry, honesty, compassion, integrity, etc. embedded in Yoruba culture.

21 Timehin, S. O., Moral Decadence: Causes, Effects and Solution. (Osogbo: Fountain University Press), 2013:138 